\title{
LA EXCAVACIÓN ARQUEOLÓGICA DEL PATIO DE SAN MARTÍN EN LA ALJAFERÍA (FEBRERO-MAYO 1985). INFORME PRELIMINAR
}

Por

JUAN A. SOUTO

El día 15 de noviembre de 1985 hice entrega a las Cortes de Aragón - Parlamento autónomo- de la memoria correspondiente a la excavación arqueológica del patio llamado de San Martín en el palacio de la Aljafería (1). Con mi esperanza puesta en poder publicar su contenido en un futuro próximo, vaya de momento el presente informe, al que estas páginas ofrecen su espacio con la amabilidad de que hacen gala.

Entre 1983 y 1985 pude realizar, solo o con la colaboración de mi buen amigo y colega D. Enrique Ariño, varios trabajos en el interior del palacio (figura 1) (2). Mi última intervención consistió en la excavación arqueológica del patio de San Martín, que las Cortes de Aragón han de ocupar con motivo de su instalación en el edificio. La memoria redactada y entregada al Parlamento consiste en la relación del desarrollo de la excavación y él estudio de los materiales medievales - únicos que ofrecen, junto con un fragmento cerámico de época romana, auténtico interés arqueológico-

El día 12 de febrero de 1985 comenzaron las excavaciones, que se desarrollaron hasta el 31 de mayo del mismo año. Mi objetivo primordial era realizar dicho trabajo

11) Cf. mi inédita Memoria de la excavación del patio de San Martin en el palacio de la Aljaferia de Zaragoza, Zaragoza, noviembre de 1985. Fecha de entrada en las Cortes de Aragón: 15 de noviembre de 1985; número de entrada en el Registro General de dicho organismo: 1597. Consta de 46 páginas de texto, 121 dibujos de cerámica y 6 planos como anexo. La dirección de la excavación de este patio me fue encargada por las Cortes de Aragón por resolución de la mesa del día 16 de abril de 1984 , y fue formalizada según contrato de fecha 4 de febrero de 1985.

(2) Cf. SQUTO, \&. A., «Sobre el papel del arqueólogo medievalista en las obras de restauración de monumentos arquitectónicos. Los ejemplos del palacio de Cetina, La Seo del Salvador v la Aljaferla (Zaragozalm, I Congreso de Arqueología Medieval Española, Huesca, abril de 1985, actas en prensa.

La figura 1 muestra en trama rayada oblicua las zonas de mi intervención desde 1983 a 1985. Las claves de las mismas son las siguientes:

- PW-S: Sondeos en el patio occidental.

- PSI-AS: Planimetría de la alberca meridional del patio de Santa isabel.

- PSI-AN: Idem de la alberca septentrional del mismo.

- PSM: Excavación del patio de San Martín.

Sobre los sondeos del patio occidental, v. ARIÑO, E. y SOUTO, J. A., "Sondeos estratigráficos en la Aljafería de Zaragoza loctubre-diciembre 1983/m, Sharq al-Andalus. Estudios Árabes, 2, 1985, pp. 121-4. 
con vistas a recuperar niveles arqueológicos intactos al mienos desde época renacentista. El estado inicial del patio en febrero de 1985 y el estudio de planimetrias de los siglos XVI a XX con cuyos facsímiles conté en todo momento me llevaron a dividir el patio en una serie de contextos o áreas que pueden verse en la figura 2 y cuya explicación se detallará en mi futura publicación. El método que se procuró seguir para excavar estos contextos fue en todo momento el mismo, dando preponderancia al sentido horizontal sobre el vertical, excavando de esta forma superficies homogéneas. Bien pronto se hizo manifiesto que el patio, objeto de profundas remodelaciones desde sus orígenes, no presentaba nivel alguno que pudiera considerarse arqueológicamente intacto: conducciones sanitarias, fundaciones de edificios cuartelarios e incluso una cisterna de hormigón armado ocupando gran parte del contexto AS (figura 2 l habian arrasado en buena medida con cualquier tipo de resto mueble o de nivel anterior.

Los únicos restos arquitectónicos que merecen interés de entre todos los puestos al descubierto a lo largo de la excavación son los correspondientes a época medieval: de hecho, los demás elementos están relativamente bien documentados gracias a las planimetrías militares $y$, por otra parte, excesivamente alterados los unos por los otros como para poder sacar en limpio alguna posible conclusión, que además sería de un interés muy relativo en comparación con la arquitectura medieval recuperada. No se encontraron restos arquitectónicos de épocas preislámicas.

La noticia más interesante es sin duda la de los restos islámicos: dos series de muros de hormigón grisáceo formado por cal y cantos rodados de gran tamaño. Una de ellas es contigua a la puerta principal del palacio (3) y se dispone formando una entrada interior en recodo que incluve los restos de un par de jambas de alabastro con acabado almohadillado (4). No parece haber, al menos de momento, mayores problemas para atribuir a esta entrada una cronología hüdt (5). La segunda serie de muros se encuentra en la parte occidental del patio, contigua y paralela a las dependencias correspondientes a la zona central del conjunto palatino, y su intepretación es menos sencilla (6). Valga de momento, y hasta que aparezca mi publicación con

(3) Sobre esta puerta, v. EWERT. Ch., iTradiciones omeyas en la arquitectura palatina de la época de los taifas. La Aliaferia de Zaragoza" XXIII Congreso Internacional de Historia del Arte, II, Granada, 1977, 0. 64 y fig. 2; y ZOZAYA, J., "ISFamic Fortifications in Spain: Some Aspects", Papers in Iberian Archaeology. B. A. R. International Series, 193, 1984, 0 p. 636 y ss.

(4) Sillares con acabado almohadillado hay en la torre pre-hũdi de la Aljafería, así como en ailgunos de los sillares de alabastro originales de los cubos de la muralla hüdú.

(5) De sus criterios de cronología y su relación con la portada conocida hasta ahora (w. n. 3 ) me ocuparé en la publicación de mi trabajo. La de la entrada en recodo es una técnica conocida en el mundo islámico al menos desde la fundación de Bagdad por al-Manşur en el s. VIIl. Sobre sus origenes, y. CRESWELL, K. A. C. Compendio de arquitectura paleoislámica, Sevilla, 1979. pp. 273-8. Sobre la Bagdad de al-Manşur, v. LASSNER, J., The Topography of Baghdad in the Early Middle Ages, Detroit, 1970, e ID. The Shaping of ${ }^{\circ}$ Abbasid Rule, Princeton, N. Jersey, 1980, pp. 163-241. En al-Andalus fue corriente este tipo de ingreso tanto en la arquitectura militar como en la civil - viviendas y alcázares - . Un ejemplo de época omeya se encuentra en el hisn de Gormaz (Soria), cuyo conocimiento detallado debo a las indicaciones personales de D. Juan Zozaya. Como ejemplos de época taifa pueden apuntarse la Puerta Nueva o de los Pesos y la Monaita. en el Albaicín de Granada; la antigua puerta de Elvira, en la misma ciudad; una puerta interior en la alcazaba de Málaga y la desaparecida de.Santa Bárbara en Guadix (Granada), según TORRES BALBAS, L., "Las puertas en recodo en la arquitectura militar hispanomusulmana». Al-Andalus, XXV, 1960, pp. 247-8. De época almorávid, directamente derivadas de las anteriores, son las puertas en recodo de la cerca de Niebla (Huelval lznájar (Córdoba) y Zagora (Marruecos), según toem, pp. 429-32; la del castillo de Fuengirola (Málaga) (cf. ROMAN RiECHMANN, C., "El castillo de Fuengirola (II). El castillo árabe" "Castillos de España, 22 (89), 1984, p. 48, ilust en pp. 42 y 43 . Esta puerta es analizada por Zozaya en su artículo citado en la nota 2); la de la uTorre del Mig” en la alcazaba de Denia (Alicante) (cf. AZUAR RUIZ, R.; "La portada interior dè la "Torre del Mig" de la alcazaba de Denia", Sharq al-Andalus. Estudios Arabes, 1, 1984, esp. pp. 124-5 y lárn. II); $y$ la del hișn de Aspe (Alicante) (sobre este hişn, v. AZUAR RUIZ, R., Castellologla medieval alicantina: Area meridional, Alicante, 1981, pp. 85-111. Pude comentar con D. Rafael Azuar ciertos aspectos relativos a esta entrada en el propio yacimiento, durante la campaña de excavaciones de 1984). Zozava hace una revisión general acerca de la problemática de las entradas en recodo en las fortificaciones andalusies en su articulo citado en la n. 3 .

(6) ¿Se trataría de estructuras pre-hüdies? ¿Podrian ser, por el contrario, restos de posibles estancias de carácter intimo dispuestas en época hưdi al margen de la zona central del palacio, tal como ya sospecharon los Dres. Iñiguez y Ewert? 
su estudio pormenorizado, apuntar que hoy por hoy prefiero optar por la prudencia y dejar sus cuestiones cronológicas y funcionales como inseguras.

En lo que se refiere a hallazgos cerámicos, apareció un frogmento de sigillata hispana tardía, al menos doce fragmentos que en principio he considerado islámicos, 108 fragmentos medievales cristianos - de los que son mayoría los del tipo de cerámica conocida como "cerámica gris" - y una gran cantidad de fragmentos cerámicos $y$ hallazgos menores post-medievales, que han sido debidamente catalogados, siglados y conservados, de forma que quienquiera que sea pueda acometer su estudio en el futuro.

Los hallazgos menores de cronología medieval han sido dos: un fragmento de fuste de pudinga rosácea, parte sin duda de una columna del palacio hūdī, y una moneda cristiana de cobre.

La totalidad de los hallazgos fue entregada al Museo Provincial de Zaragoza el día 3 de junio de 1986. 